\title{
PENERAPAN MODEL CONTEXTUAL TEACHING AND LEARNING (CTL) UNTUK MENINGKATKAN PEMAHAMAN MATA PELAJARAN IPS
}

\author{
Titoh Tohariah \\ SD N Karangtengah, Kawalu, Tasikmalaya, Indonesia \\ Email: titohtohariah4@gmail.com
}

\begin{abstract}
Based on the observation result conducted in class III SD Negeri Karangtengah, Kota Tasikmalaya, it is found that the learning outcomes of class III students in Social Sciences have not reached the KKM as determined by the school. This problem is caused by several factors, at which one of them is that Social Sciences learning process in class III SD Negeri Karangtengah, Tasikmalaya City have not implemented a conducive learning yet. Therefore, the purpose of this study is to determine student learning outcomes after using the Contextual Teaching and Learning (CTL) model. Classroom Action Research (PTK) is employed in this research involving the third grade students of SD Negeri Karangtengah, Tasikmalaya City as the subject. Based on the results obtained from the initial data, it is revealed that the student learning outcomes covers 11 students who are complete and 17 students are not complete with a percentage of 39.29\% complete and $60.71 \%$ incomplete. In cycle $I$, it is obtained an increase in completeness as many as 18 students (64.29\%) who are complete and 3 students (35.71\%) are not complete. In cycle II, there is also an increase of student completeness, $i$ e., almost all of students are complete with a percentage of $89.29 \%$.
\end{abstract}

Keywords: Contextual Teaching and Learning (CTL) Model and Student Understanding

\begin{abstract}
ABSTRAK
Berdasarkan hasil observasi diperoleh informasi bahwa di kelas III SD Negeri Karangtengah Kota pada pembelajaran IPS, belum mencapai KKM sebagaimana yang telah ditentukan pihak sekolah. Permasalahan tersebut diakibatkan oleh beberapa faktor, salah satunya karena pembelajaran IPS di kelas III SD Negeri Karangtengah Kota Tasikmalaya masih kurang melakukan pembelajaran yang kondusif. Oleh sebab itu tujuan dari penelitian ini adalah untuk mengetahui hasil belajar siswa setelah menggunakan model Contextual Teaching and Learning (CTL). Penelitian ini berupa Penelitian Tindakan Kelas (PTK). Subjek penelitian ini adalah siswa kelas III SD Negeri Karangtengah Kota Tasikmalaya. Hasil penelitian menunjukkan bahwa pada paparan data hasil belajar siswa diperoleh data awal sebanyak 11 orang siswa tuntas dan 17 orang siswa belum tuntas dengan persentase $39,29 \%$ ketuntasan dan $60,71 \%$ belum tuntas. Pada siklus I diperoleh peningkatan ketuntasan yaitu sebanyak 18 orang siswa tuntas dan 3 orang siswa belum tuntas yang apabila dipersentasekan $64,29 \%$ tuntas dan $35,71 \%$ belum tuntas. Pada silkus II pun terjadi peningkatan ketuntasan siswa yaitu hampir keseluruhan siswa telah tuntas dengan prosentase $89,29 \%$.
\end{abstract}

Kata Kunci: Model Contextual Teaching and Learning (CTL), Pemahaman Siswa

Cara sitasi: Tohariah, T. (2021). Penerapan Model Contextual Teaching and Learning (CTL) untuk Meningkatan Pemahaman Mata Pelajaran IPS. J-KIP (Jurnal Keguruan dan IImu Pendidikan), 2 (1), 79-84. 


\section{PENDAHULUAN}

IPS merupakan salah satu mata pelajaran yang diberikan dimulai dari sekolah dasar (SD) sampai sekolah menengah pertama (SMP) berusaha memberikan wawasan secara komprehensif tentang peristiwa, fakta, konsep, dan generalisasi yang berkaitan dengan isu-isu social (Chizbullah, 2017). Pembelajaran IPS di Sekolah Dasar diharapkan dapat membina siswa untuk memahami potensi dan peran dirinya dalam berbagai tata kehidupan. Dengan demikian menurut Mulyana, et. al. (2016) melalui mata pelajaran IPS siswa akan dibekali ilmu pengetahuan dan diarahkan untuk menjadi warga negara yang baik, yang memiliki pengetahuan dan kepedulian sosial yang berguna bagi dirinya, bagi masyarakat dan juga Negara.

Dari observasi awal pada proses pembelajaran, apabila dilakukan suatu proses persentase terhadap keberhasilan (ketuntasan berdasarkan KKM) maka dari 28 siswa, yang memperoleh nilai sama dengan atau lebih dari KKM adalah 11 orang dan 17 lainnya masih berada di bawah KKM. Permasalahan tersebut diakibatkan oleh beberapa faktor yaitu diantaranya pembelajaran IPS di kelas III SD Negeri Karangtengah Kota Tasikmalaya masih kurang melakukan pembelajaran yang kondusif. Guru masih melakukan pembelajaran dengan cara tradisional, hanya berceramah mengenai materi yang diajarkan kemudian dilanjutkan dengan tanya jawab (itu pun jika ada siswa yang bertanya) dan evaluasi (berupa menjawab soal), jadi konsep-konsep IPS yang diperoleh siswa yang hanya berupa konsep-konsep yang sudah jadi dari buku pelajaran yang sudah ada atau dari guru. Siswa tidak diberi kesempatan untuk mencari tahu dari mana konsep IPS tersebut didapat. Pendidikan IPS di sekolah dasar seharusnya bertujuan agar siswa dapat menyenenangi IPS sehingga siswa akan dapat mengikuti perkembangan pembelajaran IPS. Sehingga dengan pembelajaran IPS di sekolah dasar akan membangun pemahaman siswa, rasa ingin tahu siswa untuk membentuk konsep IPS yang mereka dapat.

Dari beberapa data tersebut terdapat beberapa kajian yang merupakan proses pembelajaran yang terjadi di dalam kelas pada saat pelaksanaan pembelajaran yang dimana di dalamnya tentu terdapat beberapa kekurangan yang perlu direfleksikan dan bagaimana cara penyelesaian masalahnya agar apa yang menjadi tujuan suatu pembelajaran dapat berjalan dengan lancar dan terarah.

Oleh karena itu, guru harus membuat suatu pengajaran lebih efektif juga menarik sehingga bahan pelajaran yang disampaikan akan membuat siswa merasa senang dan merasa perlu untuk mempelajari bahan pelajaran tersebut. Dalam kegiatan belajar mengajar diperlukan sebuah pendekatan (Afifah, et. al. 2020). Guru harus memiliki pendekatan mengajar yang baik maupun memilih pendekatan pembelajaran yang tepat dan sesuai dengan konsep mata pelajaran yang akan disampaikan. Salah satu pendekatan pembelajaran yang ada adalah Contextual Teaching and Learning (CTL). Pendekatan pembelajaran kontekstual (Contextual Teaching and Lerning/ CTL) merupakan suatu proses pendidikan yang holistik dan bertujuan memotivasi siswa untuk memahami makna materi pelajaran yang dipelajarinya dengan mengkaitkan materi tersebut dengan konteks kehidupan mereka sehari-hari (konteks pribadi, sosial, dan kultural) sehingga siswa memiliki pengetahuan/ keterampilan yang secara fleksibel dapat diterapkan (ditransfer) dari satu permasalahan ke permasalahan lainnya. CTL merupakan suatu konsep pembelajaran yang dimana seorang siswa bukan hanya diarahkan untuk mempelajari materi tertentu saja, tetapi diarahkan untuk mengalami sendiri secara alamiah apa yang ada dalam materi pembelajaran.

Dalam mata pelajaran IPS, guru harus membangun siswa untuk lebih aktif dalam kegiatan pembelajaran dan meningkatkan minat siswa dalam menanggapi materi yang telah disampaikan sehingga akan memperoleh hasil belajar yang baik atau memuaskan, oleh karena itu untuk memberikan hal-hal tersebut akan dibentuk suatu cara atau srategi pembelajaran yang akan memudahkan guru dan siswa dalam kegiatan belajar mengajar yaitu melalui pendekatan Contextual Teaching and Learning (CTL). 
Berdasarkan identifikasi masalah tersebut, maka dapat dirumuskan masalah pada penelitian ini adalah "Bagaimana hasil belajar siswa dari penggunaan model Contextual Teaching and Learning (CTL) tersebut?".

\section{METODE PENELITIAN}

\section{A. Subyek dan Waktu Penelitian}

Lokasi penelitian yang menjadi tujuan dari penelitian ini adalah kelas III SD Negeri Karangtengah Kota Tasikmalaya, adapun alasan kenapa memilih SD Negeri Karangtengah Kota Tasikmalaya hal ini dikarenakan permasalahan yang terjadi pada siswa di kelas III SD Negeri Karangtengah Kota Tasikmalaya, peneliti bertugas sebagai pengajar pada sekolah tersebut, sehingga proses penelitian yang akan dilakukan akan mempermudah bagi peneliti untuk mengenal terlebih dahulu karakteristik dari permasalahan dan karakteristik dari siswa sebelum dilakukannya penelitian. Penelitian tindakan kelas ini dilaksanakan sebanyak 2 siklus dimana dalam setiap siklus dilaksanakan sebanyak 2 kali pertemuan, siklus I dilaksanakan pada tanggal 14 dan 17 Oktober 2019 sedangkan siklus II dilaksanakan pada tanggal 4 dan 7 Nopember 2019

\section{B. Prosedur Penelitian}

\section{Siklus I}

\section{a. Perencanaan}

Arikunto, et. al. (2008) menjelaskan bahwa: "Kegiatan planning antara lain sebagai berikut: (1) identifikasi masalah, (2) perumusan masalah dan analisis penyebab masalah, dan (3) pengembangan intervensi (Action/Solution)." Intervensi pada penelitian ini berupa penggunaan model Contextual Teaching and Learning (CTL).

\section{b. Pelaksanaan}

Kajian Mengenai Tahap Pelaksanaan menurut pendapat dari Wiraatmadja (2009) bahwa "pada tahap ke-2 dari penelitian tindakan adalah pelaksanaan yang merupakan implementasi atau penerapan isi rancangan, yaitu mengenakan tindakan kelas". Proses penelitian tindakan kelas ini maka dalam proses pelaksanaan pembelajaran diterapkan langkah-langkah model pembelajaran dengan menggunakan model pembelajaran kontekstual.

\section{c. Observasi dan Pengumpulan Data}

Menurut pendapat dari Wiraatmadja (2009) yang menjelaskan bahwa "pada tahap ke-3, yaitu kegiatan pengamatan yang dilakukan oleh pengamat". Pada tahap observasi ini dilakukan suatu pengamatan akan proses pembelajaran yang terjadi pada penelitian tindakan kelas, kegiatan observasi ini dilakukan bersamaan dengan tahap pelaksanaan tindakan, sehingga memudahkan proses pengumpulan data pada penelitian tindakan kelas, dan dalam proses observasi ini digunakan instrumen penelitian, baik itu dalam instrument penelitian yang digunakan untuk mengumpulkan data proses maupun instrumen penelitian yang digunakan untuk mengumpulkan data hasil belajar siswa.

\section{d. Refleksi}

Arikunto, et al. (2008) menjelaskan tentang tahapan refleksi. Tahapan ini dimaksudkan untuk mengkaji secara menyeluruh tindakan yang telah dilakukan, berdasarkan data yang telah terkumpul, kemudian dilakukan evaluasi guna menyempurnakan tindakan berikutnya.

\section{Siklus II}

\section{a. Perencanaan}

Pada tahap perencanaan siklus II ini dilakukan suatu proses perencanaan tindakan yang akan dilakukan sebgai bentuk dari penerapan dari hasil refleksi yang dilakukan terhadap permasalahan yangterjadi pada iklus I, akan tetapi proses dan 
konsep umum dari langkah perencanaan siklus II ini sama halnya dengan perencanaan pada siklus I.

b. Pelaksanaan

Pada tahap pelaksanaan siklus II, merupakan suatu pengaplikasian dari hasil perencanaan siklus II terhadap beberapa tindakan yang akan dilakukan sebagai bentuk dari pemecahan permasalahan yang terjadi pada proses pembelajaran maupun dalam proses penelitian tindakan kelas yang terjadi pada siklus I, konsep umum dari tahap pelaksanaan tindakan siklus II ini tetap mengacu kepada proses pembelajaran yang mengadung unsur-unsur dari model pembelajaran kontekstual yang diterapkan dalam proses pembelajaran sebagai bentuk dari hipotesisi tindakan dalam pembelajaran.

\section{c. Observasi dan Pengumpulan Data}

Pada tahapan observasi dan pengumpulan data dilakukan suatu teknik pengolahan data dan perbandingan data yang diperoleh pada siklus I dengan data yang diperoleh pada siklus II, sehingga dapat dijadikan sebagai data perbandingan keberhasilan yang diperoleh pada siklus II terhadap pencapaian target penelitian tindakan yang telah ditentukan, proses proses pengumpulan data dan observasi ini dilakukan dengan menggunakan instrument penelitian dalam bentuk tes, pedoman observasi dan catatan lapangan yang masing-masing mempunyai deskriptor penilaian dan teknik pengolahan data.

\section{d. Refleksi}

Tahap refleksi yang dilakukan pada siklus II sama halnya dengan tahap refleksi yang dilakukan pada siklus I, yaitu dengan melakukan suatu perbandingan data yang diperoleh dalm bentuk temuan untuk dilakukan suatu analisis pencapaian dari deskriptor penilaian dan dilakukan suatu bentuk tindakan terhadap permasalahan yang terjadi dalam proses pembelajaran. Namun pada tahap refleksi siklus II ini apabila masih terdapat permasalahan akan dilakukan suatu tindakan perbaikan diluar penelitian tindakan kelas, hal ini dikarenakan pada siklus II diperoleh data yang telah mencapai target yang ditentukan yaitu $80 \%$ pencapaian target indikator penilaian dan $80 \%$ ketuntasan siswa pada hasil belajar.

\section{Instrumen Penelitian}

\section{a. Test}

Kusuma (Arikunto, 2005) berpendapat bahwa Tes adalah "suatu alat atau prosedur yang sistematis dan objektif untuk memperoleh data-data atau keteranganketerangan yang diinginkan tentang sesorang, dengan cara yang boleh dikatakan tepat dan cepat". Penyusunan tes berdasarkan beberapa pertimbangan dari tujuan pembelajaran dan bersifat objektif untuk memperoleh data perkembangan kemampuan siswa, pada proses penelitian tindakan kelas ini tes dibuat berdasarkan pencapaian dari tujuan pembelajaran dan cakupan materi pembelajaran dalam bentuk uraian isian.

\section{b. Pedoman Observasi}

Pelaksanaan pembelajaran dengan model pembelajaran kontekstual dilakukan dengan menerpakan asas-asas pada model pembelajaran kontekstual tersebut kepada kinerja guru dan aktifitas siswa pada saat penerapan langkah model pembelajaran kontekstual, yang akan di observasi dengan menentukan terlebih dahulu aspek yang akan di observasi dalam proses penelitian, dalam hal ini menurut pendapat dari Mulyasa (2009) bahwa "pedoman observasi adalah instrument yang digunakan untuk mengadakan pengamatan terhadap aktifitas dan kretifitas peserta didik dalam pembelajaran, baik dikelas maupun diluar kelas." 


\section{c. Catatan Lapangan}

Wiraatmadja (2009) yang mengemukakan bahwa "Catatan lapangan memuat deskriptif berbagai kegiatan suasana kelas, iklim sekolah, kepemimpinan, berbagai bentuk interaksi sosial, dan nuansa lainnya". Dari pendapat tersebut dapat disimpulkan bahwa catatan lapangan dapat digunakan sebagai alat untuk memperoleh tinjauan dari situasi dan keadaan pembelajaran, hal ini dapat dijadikan sebagai suatu data pertimbangan bagi pengkoreksian dari proses pembelajaran.

\section{Indikator Keberhasilan}

Penelitian ini dilakukan berdasarkan hasil tes formatif yang hanya $39 \%$ siswa yang tuntas belajar memperoleh nilai diatas KKM Pelajaran IPS kelas III SD Negeri Karangtengah Kota Tasikmalaya yaitu 70 . Adapun hasil penelitian yang diharapkan adalah $80 \%$ siswa memperoleh nilai diatas KKM.

\section{HASIL DAN PEMBAHASAN}

Pada tahap perencanaan siklus I dilakukan suatu proses perencanaan terhadap pembuatan RPP dengan menerapkan langkah-langkah pembelajaran model pembelajaran kontekstual yang digunakan untuk meningkatkan pemahaman siswa dalam menghargai keragaman suku bangsa dan budaya di Indonesia. Selain dari pada itu dilakukan juga proses pembuatan media pembelajaran dalam bentuk media gambar, proses pembuatan LKS yang menerapkan unsur-unsur model pembelajaran kontekstual dan proses pembuatan instrument penelitian yang terdiri dari tes, pedoman observasi dan catatan lapangan, data yang dihasilkan pada siklus I tahap perencanaan ini adalah dengan jumlah skor keseluruhan 12 yang apabila dipersentasikan maka akan mencapi persentase $100 \%$.

Tahap pelaksanaan siklus I ini mengacu kepada proses pembelajaran yang mengandung unsur-unsur model pembelajaran kontekstual yaitu kontruktivisme, inkuiri, bertanya, masyarakat belajar, pemodelan dan refleksi. Pada tahap pelaksnaan siklus I ini diperoleh jumlah skor keseluruhan 33 dengan persentase $68,75 \%$.

Hasil belajar yang di ingingkan dalam proses pembelajaran dan proses penelitian tindakan kelas ini adalah meningkatkan pemahaman siswa dalam menganalisis dan memahami persebaran daerah asal suku bangsa di Indonesia, memperoleh gambaran hasil belajar siswa pada siklus I adalah 18 orang siswa yang tuntas $(64,29 \%)$ dan 10 orang siswa yang belum tuntas $(35,71 \%)$ atau meningkat sebesar $25,00 \%$ dari pra siklus.

Tahap perencanaan siklus II ini merupakan langkah perencanaan terhadap tindakan permasalahan yang terjadi pada siklus I, adapun data yang diperoleh pada siklus II tahap perencanaan adalah dengan jumlah skor keseluruhan 12 yang apabila dipersentasikan maka akan mencapai persentase $100 \%$.

Tahap pelaksanaan siklus II merupakan tahap penerapan dari proses perencanaan yang dilakukan pada siklus II terhadap permasalahan yang terjadi pada siklus I, adapun hasil yang diperoleh pada siklus I sebagai berikut jumlah skor keseluruhan 46 dengan persentase $95,83 \%$. atau meningkat sebesar 27,08 dari tahap pelaksanaan siklus I.

Paparan data yang dihasilkan pada hasil belajar siswa siklus II yaitu dengan jumlah siswa yang tuntas sebanyak 25 orang dengan persentase $89,29 \%$ dan siswa yang belum tuntas hanya sebanyak 3 orang siswa atau sebesar $10,71 \%$. pada siklus II mengalami peningkatan sebesar $25,00 \%$ dari siklus I.

\section{KESIMPULAN}

Pada data proses kinerja guru tahap perencanaan siklus I memperoleh persentase pencapian indikator sebesar $100 \%$ dan pada siklus II memperoleh persentase $100 \%$ pencapian indikator penilaian, sedangkan untuk tahap pelaksanaan diperoleh persentase pada siklus I sebesar 
$68,75 \%$ dan meningkat pada siklus II sebesar $95,83 \%$. Sehingga dari hasil kinerja guru tersebut telah mencapai target yang ditentukan yaitu sebesar $80 \%$ pencapaian indikator penilaian. Pada paparan data hasil belajar siswa dengan tujuan meningkatkan kemampuan dalam menghargai keragaman suku bangsa dan budaya di Indonesia data awal sebanyak 11 orang siswa tuntas dan 17 orang siswa belum tuntas dengan persentase $39,29 \%$ ketuntasan dan $60,71 \%$ belum tuntas, pada siklus I diperoleh peningkatan ketuntasan yaitu sebanyak 18 orang siswa tuntas dan 10 orang siswa belum tuntas yang apabila dipersentasekan $64,29 \%$ ketuntasan dan $35,71 \%$ belum tuntas. Pada silkus II pun terjadi peningkatan ketuntasan siswa yaitu 25 orang siswa atau sebesar $89,29 \%$ dan yang belum tuntas hanya sebanyak 3 orang siswa atau sebesar $10,71 \%$.

Berdasarkan data tersebut maka dapat disimpulkan bahwa dengan Penerapan Model Contextual Teaching and Learning dapat meningkatan pemahaman siswa dalam memahami pemetaan wilayah di Nusantara, dimana pembelajaran dapat ditindaklanjuti dan diminimalisir sehingga tercapai dari tujuan pembelajaran dan perbaikan proses pembelajaran.

Dengan pembuktian keberhasilan penerapan model Contextual Teaching and Learning untuk meningkatkan pemahaman kemampuan siswa pada mata pelajaran pendidikan ilmu pengetahuan sosial di kelas III SD Negeri Karangtengah Kota Tasikmalaya maka dapat menjadi pertimbangan agar lebih dikembangkan model pembelajaran Contextual Teaching and Learning dalam proses pembelajaran.

\section{REKOMENDASI}

Penerapan model pembelajaran kontekstual pada proses pembagian kelompok siswa diharapkan lebih mempertimbangkan terhadap keseimbangan dari jumlah kelompok siswa yang berada dalam kelompok siswa unggul, tengah dan asor dalam satu kelompok pembelajaran.

\section{UCAPAN TERIMAKASIH}

Penulis mengucapkan terima kasih kepada guru kelas III dan kepala SD Negeri Karangtengah Kota Tasikmalaya yang telah mendukung terhadap pelaksanaan penelitian ini.

\section{DAFTAR PUSTAKA}

Afifah, A. N., Ilmiyati, N \& Toto. (2020). Pengaruh Model Project Based Learning (PjBL) dengan Pendekatan STEM Terhadap Penguasaan Konsep dan Keterampilan Berpikir Kritis Siswa. J-KIP (Jurnal Keguruan dan IImu Pendidikan), 1 (2), 33-40.

Arikunto, S. (2005). Dasar-Dasar Evaluasi Pendidikan. Bandung: PT. Bumi Aksara.

Arikunto, S., Suhardjono \& Supardi. (2008). Penelitian Tindakan Kelas. Jakarta: PT. Bumi Aksara.

Chizbullah, Y. I., Kurnia, D., \& Iswara, P. D. (2017). Penerapan Model Contextual Teaching Learning (CTL) Berbantuan Media Lingkaran Untuk Meningkatkan Hasil Belajar Pada Materi Menunjukan Jenis Dan Persebaran Sumber Daya Alam. Jurnal Pena IImiah, 2(1): 21212130 .

Mulyana, M. A., Hanifah, N., \& Jayadinata, A. K. (2016). Penerapan Model Kooperatif Tipe Numbered Heads Together (NHT) Untuk Meningkatkan Hasil Belajar Siswa Pada Materi Kenampakan Alam Dan Sosial Budaya. Jurnal Pena IImiah, 1(1) : 331-340.

Mulyasa. (2009). Praktik Penelitian Tindakan Kelas. Bandung. Rosda Karya.

Wiraatmadja, R. (2009). Metode Penelitian Tindakan Kelas. Bandung: Remaja Rosdakarya. 